\title{
Current status and prospect of medical and surgical management for thoracic empyema
}

\author{
Mitsunori Higuchi ${ }^{1}$, Hiroyuki Suzuki ${ }^{2}$ \\ ${ }^{1}$ Department of Thoracic Surgery, Aizu Medical Center, Fukushima Medical University, Aizuwakamatsu, Japan; ${ }^{2}$ Department of Chest Surgery, \\ Fukushima Medical University School of Medicine, Fukushima, Japan \\ Contributions: (I) Conception and design: None; (II) Administrative support: None; (III) Provision of study materials or patients: None; (IV) \\ Collection and assembly of data: M Higuchi; (V) Data analysis and interpretation: None; (VI) Manuscript writing: Both authors; (VII) Final approval \\ of manuscript: Both authors. \\ Correspondence to: Mitsunori Higuchi, MD, PhD. Department of Thoracic Surgery, Aizu Medical Center, Fukushima Medical University, 21-2 \\ Maeda, Tanisawa, Kawahigashi, Aizuwakamatsu 969-3492, Japan. Email: higuchi@fmu.ac.jp.
}

\begin{abstract}
We sometimes encounter patients with chronic empyema of their thoracic cavity with or without air leakage. These patients often experience mental and physical problems because of restrictions in daily life and long-term treatment. Thoracic empyema is classified as acute or chronic empyema. The former is treated by antibiotics, thoracic drainage, fibrinolysis, or debridement under video-assisted thoracic surgery (VATS), while the latter is treated by managing the infection and reducing the dead space of the thoracic cavity. In this review, we summarize the procedures for various treatment methods and technical skills in the management of thoracic empyema. Chest physicians should consider the advantages and disadvantages of each method and choose an appropriate technique or possibly a combination of techniques to obtain an optimal outcome in the treatment of thoracic empyema. The techniques and knowledge described in this review will be useful for many physicians' clinical work. Treatment methods differ among institutions, and a guideline for thoracic empyema is needed to standardize treatment of this entity in future.
\end{abstract}

Keywords: Empyema; chest drainage; fibrinolysis; video-assisted thoracic surgery (VATS); open surgery

Received: 23 January 2020; Accepted: 27 February 2020; Published: 25 November 2020.

doi: $10.21037 /$ ccts.2020.02.09

View this article at: http://dx.doi.org/10.21037/ccts.2020.02.09

\section{Introduction}

Thoracic empyema, which is defined as purulent collections within the thoracic cavity due to a pleural space infection, is associated with severe morbidity and mortality in both adults and children despite optimal treatment (1-4). This entity was first described in the fifth century B.C. by Hippocrates in his aphorisms, who proposed drainage as a treatment (5). For hundreds of years thereafter, empyema was treated using open drainage. However, most cases are now initially treated using antibiotics with or without repeated thoracentesis or tube drainage. Surgical approaches including video-assisted thoracic surgery (VATS) or open thoracotomy are usually reserved for patients with a deteriorated clinical condition following failed conservative treatment. VATS has been shown to result in earlier and more complete resolution of empyema than tube drainage alone $(6,7)$. Fibrinolysis has also been shown to be superior to tube drainage alone (8-10). The management of thoracic empyema is empirical, and its treatment strategy is controversial. Furthermore, limited data from controlled clinical trials are available to guide the management of thoracic empyema. This review highlights significant findings in empyema management to help readers comprehend the current status of this field.

\section{Epidemiology}

Recent epidemiologic studies have indicated that the incidence of empyema has been increasing during the last 
few decades (11). In 2016 in Japan, 2,833 cases of empyema were reported and hospital mortality rate was $6.9 \%$ (12). In the United Sates, the estimated incidence of parapneumonic empyema is 6 cases per 100,000 people, and the hospital mortality rate in the adult population is approximately $16.1 \%$ (13). Risk factors of empyema include diabetes mellitus, gastroesophageal reflux, poor dental hygiene, chronic lung disease, alcohol abuse, and so on. Empyema may develop as a complication of pulmonary infection, thoracic and abdominal surgery, trauma, and iatrogenic procedures. However, pleural infection may also occur as a primary infection without pneumonia.

\section{Pathophysiology and classification}

\section{Acute empyema}

Thoracic empyema is the accumulation of purulent collections within the pleural cavity. Empyema is classified as acute or chronic and is also classified as localized or diffuse. Empyema is divided into three stages (14): stage I is an acute exudative phase in which the visceral pleura remains elastic and the dimensions of the thoracic cavity are maintained. Stage II is a subacute fibrinopurulent phase characterized by turbid, infected fluid with fibrin deposits constructing bridges that separate the effusions. Stage III is chronic organizing phase in which this construct is replaced by formal granulation tissue. Successful treatment of acute empyema requires immediate treatment with adequate antibiotics and tube drainage to prevent recurrence and chronicity. Most affected patients have small and uncomplicated effusion that can be treated conservatively with continued antibiotics, thoracentesis and observation. However, patients with loculated pleural effusion or purulent effusion on thoracentesis should be considered prompt insertion of a chest tube. Patients with loculated parapneumonic effusion (stage II, subacute phase), particularly those patients whose lung fails to reexpand, should be considered for early VATS procedure or intrapleural fibrinolytics $(15,16)$.

\section{Chronic empyema}

Empyema lasting $\geq 4$ weeks is classified as chronic empyema (17). At stage III empyema, the cloudy fluid begins to organize and form granulation tissue. The continuous inflammation of the infectious process involves in the formation of a fibrin peel on the visceral and parietal pleural surface. Continuation of this process also contributes contraction of the affected thorax in addition to a mediastinal shift toward the affected side and rib space narrowing. In general, chronic empyema is characterized by thickened visceral and parietal fibrin peels that hamper the ability of the affected lung to re-expand. At stage III empyema, chest tube drainage is no longer effective, therefore, chronic condition of pleural cavity needs surgical procedure. The purpose of surgical treatment is to remove purulent effusion, infected tissue and thickened pleura, and finally to close the empyema space to avoid recurrence. The selection of the initial treatment depends on the conditions of the patient's pleural cavity and lung parenchyma.

\section{Classification by American Thoracic Society}

The American Thoracic Society proposed a classification system in 1962 based on the natural history of empyema (Table 1) (14). In this classification, empyema is divided into three stages: exudative phase, fibrinopurulent phase and organized phase. The exudative phase lasts for several days and is characterized by a free-moving effusion in the pleural space. The fibrinopurulent phase is characterized by a reduced intrapleural fibrinolysis that causes fibrin deposition on the visceral and parietal pleura and is also characterized by a cloudy, viscous fluid. The organized phase is characterized by the fibrin and collagen deposition, resulting in fibrous thickening of the pleura. This classification is useful in practice and is still employed because the method of treatment is totally different in each stage or phase.

\section{Light's classification}

According to Light (18), thoracic empyema is classified into seven categories as shown in Table 2. This classification has four variables: fluid bacteriology, fluid property, fluid chemistry, and fluid $\mathrm{pH}$. According to this classification, a typical parapneumonic effusion meets the following criteria: the thickness of the pleural fluid is $>10 \mathrm{~mm}$, the pleural glucose concentration is $>40 \mathrm{mg} / \mathrm{dL}$, the pleural fluid $\mathrm{pH}$ is $>7.20$, the pleural fluid lactate dehydrogenase concentration is $<1,000 \mathrm{IU} / \mathrm{L}$, and Gram stain and culture are negative. A borderline complicated parapneumonic effusion meets the following criteria: the pleural fluid $\mathrm{pH}$ is 7.00 to 7.20 , the pleural fluid lactate dehydrogenase concentration is $>1,000 \mathrm{IU} / \mathrm{L}$, the pleural fluid glucose concentration is $>40 \mathrm{mg} / \mathrm{dL}$, and Gram stain and culture 
Table 1 Three-stage classification by the American Thoracic Society

\begin{tabular}{|c|c|c|c|}
\hline & Exudative phase (stage I) & Fibrinopurulent phase (stage II) & Organized phase (stage III) \\
\hline $\begin{array}{l}\text { Pathophysiology of pleural } \\
\text { effusion and pleura }\end{array}$ & Low cell content & $\begin{array}{l}\text { High cell content and fibrin } \\
\text { depositions over the pleural } \\
\text { surfaces and fibrinous strands } \\
\text { within the fluid }\end{array}$ & Fibroblast growth and fibrosis \\
\hline \multirow[t]{2}{*}{ Intrathoracic condition } & Re-expandable lung & $\begin{array}{l}\text { Tendency for development of } \\
\text { loculations and formations of } \\
\text { membranes }\end{array}$ & $\begin{array}{l}\text { Inelastic membranes over the } \\
\text { pleural surfaces }\end{array}$ \\
\hline & & Beginning constriction of the lung & Trapped lung \\
\hline
\end{tabular}

Table 2 Light's classification

\begin{tabular}{|c|c|c|c|c|c|c|}
\hline Class & $\begin{array}{l}\text { Characteristics of } \\
\text { effusion }\end{array}$ & Bacteriology & $\begin{array}{l}\text { Imaging } \\
\text { findings }\end{array}$ & Biochemistry & $\mathrm{pH}$ & Treatment \\
\hline Class 1 & $\begin{array}{l}\text { Nonsignificant } \\
\text { parapneumonic } \\
\text { effusion }\end{array}$ & $\begin{array}{l}\text { Gram stain } \\
\text { and culture } \\
\text { negative }\end{array}$ & $\begin{array}{l}<10 \mathrm{~mm} \text { thick } \\
\text { on decubitus } \\
\text { X-ray }\end{array}$ & - & - & $\begin{array}{l}\text { No thoracentesis } \\
\text { indicated }\end{array}$ \\
\hline Class 2 & $\begin{array}{l}\text { Typical parapneumonic } \\
\text { effusion }\end{array}$ & $\begin{array}{l}\text { Gram stain } \\
\text { and culture } \\
\text { negative }\end{array}$ & $>10 \mathrm{~mm}$ thick & Glucose $>40 \mathrm{mg} / \mathrm{dL}$ & $\mathrm{pH}>7.20$ & Antibiotics alone \\
\hline Class 3 & $\begin{array}{l}\text { Borderline complicated } \\
\text { parapneumonic } \\
\text { effusion }\end{array}$ & $\begin{array}{l}\text { Gram stain } \\
\text { and culture } \\
\text { negative }\end{array}$ & $\begin{array}{l}\text { Not loculated, } \\
\text { no frank pus }\end{array}$ & $\begin{array}{l}\text { Glucose }>40 \mathrm{mg} / \mathrm{dL} \text {, } \\
\mathrm{LDH}>1,000 \mathrm{IU} / \mathrm{L}\end{array}$ & $\begin{array}{l}7.00<\mathrm{pH} \\
<7.20\end{array}$ & $\begin{array}{l}\text { Antibiotics plus serial } \\
\text { thoracentesis }\end{array}$ \\
\hline Class 4 & $\begin{array}{l}\text { Simple complicated } \\
\text { parapneumonic } \\
\text { effusion }\end{array}$ & $\begin{array}{l}\text { Gram stain } \\
\text { and culture } \\
\text { positive }\end{array}$ & $\begin{array}{l}\text { Not loculated, } \\
\text { no frank pus }\end{array}$ & Glucose $<40 \mathrm{mg} / \mathrm{dL}$ & $\mathrm{pH}<7.00$ & $\begin{array}{l}\text { Tube thoracotomy } \\
\text { plus antibiotics }\end{array}$ \\
\hline Class 6 & Simple empyema & $\begin{array}{l}\text { Frank pus } \\
\text { present }\end{array}$ & $\begin{array}{l}\text { Single locule or } \\
\text { free-flowing }\end{array}$ & - & - & $\begin{array}{l}\text { Tube thoracotomy } \pm \\
\text { decortication }\end{array}$ \\
\hline Class 7 & Complex empyema & $\begin{array}{l}\text { Frank pus } \\
\text { present }\end{array}$ & Multiple locules & - & - & $\begin{array}{l}\text { Tube thoracotomy } \\
\text { plus thrombolytics; } \\
\text { VATS or decortication } \\
\text { often required }\end{array}$ \\
\hline
\end{tabular}

LDH, lactate dehydrogenase; VATS, video-assisted thoracic surgery.

are negative. A simple complicated parapneumonic effusion meets the following criteria: the pleural fluid $\mathrm{pH}$ is $<7.00$, the pleural fluid glucose concentration is $>40 \mathrm{mg} / \mathrm{dL}$, and Gram stain is positive; however, the fluid is not loculated and does not appear to be frank pus. A complex complicated parapneumonic effusion meets the criteria for a simple complicated parapneumonic effusion with multiloculation of the pleural fluid. In a simple empyema, the pleural fluid is frank pus and the fluid is free-flowing without loculi. If the pleural fluid is frank pus and the fluid is multiloculated, these conditions are called to have complex empyema. This classification is widely accepted and is useful for physicians 
Table 3 Categorization of risk for poor outcome among patients with parapneumonic effusion and empyema by the American College of Chest Physicians

\begin{tabular}{|c|c|c|c|c|c|c|c|}
\hline Category & $\begin{array}{l}\text { Risk of poor } \\
\text { outcome }\end{array}$ & Pleural space anatomy & & Pleural fluid bacteriology & & $\begin{array}{l}\text { Pleural fluid } \\
\text { chemistry }\end{array}$ & Drainage \\
\hline 1 & Very low & $\begin{array}{l}\text { A0: Minimal, free-flowing } \\
\text { effusion (<10 mm on lateral } \\
\text { decubitus view) }\end{array}$ & and & $\begin{array}{l}\text { Bx: Culture and Gram stain } \\
\text { results unknown }\end{array}$ & and & $\begin{array}{l}\text { Cx: pH } \\
\text { unknown }\end{array}$ & No \\
\hline 2 & Low & $\begin{array}{l}\text { A1: Small to moderate free- } \\
\text { flowing effusion ( }>10 \mathrm{~mm} \\
\text { and less than one-half } \\
\text { hemithorax) }\end{array}$ & and & $\begin{array}{l}\text { B0: Negative culture and } \\
\text { Gram stain }\end{array}$ & and & $\mathrm{C} 0: \mathrm{pH} \geq 7.20$ & No \\
\hline 3 & Moderate & $\begin{array}{l}\text { A2: Large, free-flowing } \\
\text { effusion (at least one- } \\
\text { half hemithorax) loculated } \\
\text { effusion, or effusion with } \\
\text { thickened parietal pleura }\end{array}$ & or & $\begin{array}{l}\text { B1: Positive culture and } \\
\text { Gram stain }\end{array}$ & or & $\mathrm{C} 1: \mathrm{pH}<7.20$ & Yes \\
\hline
\end{tabular}

to choose the optimal treatment of thoracic empyema because each classification recommends a therapeutic option.

\section{Guidelines by the American College of Chest Physicians}

The American College of Chest Physicians proposed guidelines on the medical and surgical treatment of parapneumonic effusions in 2000 (19). This guideline has three variables: pleural space anatomy, pleural fluid bacteriology, and pleural fluid chemistry. These variables are used to categorize patients into four separate risk levels: category 1 (very low-risk), category 2 (low-risk), category 3 (moderate-risk), and category 4 (high-risk) (Table 3).

\section{Diagnostic methods}

\section{Imaging}

A staging assessment based mainly on the start of symptoms is not easily implemented in some cases. A chest roentgenogram, ultrasound examination, and chest computed tomography (CT) scan are all required and are considered as the primary imaging modalities for effusion (20). Imaging plays three important roles in empyema management: confirmation and characterization of effusions; decision for treatment, including thoracentesis, drainage, and surgical interventions; and follow-up of the patients after treatment.

\section{Chest roentgenogram}

Imaging techniques play a fundamental role in the management of empyema. In spite of advances in imaging modalities, the chest $\mathrm{X}$-ray still plays a basic role in establishing the presence and amount of pleural effusion and guiding management during follow-up of patients. Asymmetric pleural effusion with blunting of the costophrenic angle can be recognized and smaller-volume effusions are detectable with a lateral-view roentgenogram.

\section{Chest CT}

Chest CT with intravenous contrast is optimal and has high diagnostic yield for empyema. Furthermore, a CT scan provides additional information about detailed anatomy including the mediastinum and hila. A CT scan is also necessary in some cases to confirm the characteristics of the effusion, determine the presence of pleural thickening or adhesions, and identify associated lesions such as tumors (21).

\section{Ultrasonography}

Ultrasound is an accessible, radiation-free method of visualizing free versus loculated pleural effusions. A previous study showed that ultrasound had better sensitivity for diagnosing pleural effusion than did plain radiographs (22). In the absence of clear loculation on ultrasonography, simple thoracentesis or chest tube drainage can be the standard treatment; however, patients with clear loculation require a form of thoracoscopy as an 
initial treatment (23).

\section{Thoracentesis and pleural fluid analysis}

Diagnostic thoracentesis is crucial to demonstrate the presence of pus, which identifies the empyema. Additionally, pleural fluid sampling via thoracentesis is needed for fluid analysis and diagnosis of pleural effusion (20). For patients with a known pleural infection, intercostal drainage is required for appropriate treatment, and thoracentesis without pleural tube drainage is not recommended (24). Patients with empyema who have non-purulent pleural fluid with a low $\mathrm{pH}$ or glucose concentration can be managed with antibiotics alone $(25,26)$. However, most patients who have purulent collections in their pleural cavity require VATS or open thoracotomy (27). Light (18) proposed a classification system that assists the physician in determining the aggressiveness of the initial therapy. We have described the details of this classification in the previous section of this review.

\section{Treatment modalities}

\section{Antibiotics}

Although the choice of antibiotics should be essentially on the basis of culture in pleural effusion, antibiotic therapy is started empirically; in only a minority of cases is the antibiotic therapy adapted to the laboratory results because of the low rate of positive bacteriology results. Broad-spectrum antibiotics are used for most patients with suspected or confirmed thoracic empyema. Antibiotics should be tailored to target pathogens based on epidemiology, antibiotic resistance patterns, cause of acquisition, and whether the affected patients are from a community versus healthcare setting. In communityacquired empyema, the antibiotic regimen should target common pathogens including Staphylococcus and Streptococcus species. Appropriate antibiotics include a third-generation cephalosporin plus metronidazole or a beta-lactam/betalactamase inhibitor combination. In hospital-acquired empyema, antimicrobial therapy should be directed at providing coverage for methicillin-resistant Staphylococcus aureus and Pseudomonas. Reasonable options include vancomycin plus metronidazole and antipseudomonal cephalosporin. Intravenous administration of antibiotics is often appropriate initially; however, the administration route can be changed to oral when objective clinical (e.g., improvement in temperature) and biochemical improvement (e.g., C-reactive protein) has been observed. Continuation of antibiotic therapy is generally recommended for 2 to 6 weeks depending on the degree of aforementioned infection and clinical response to the treatment (28).

\section{Chest tube drainage}

A poor response to antibiotics is requires chest tube drainage. The optimal size of the chest tube and duration of tube drainage are not determined. A large multicenter study on the chest drain diameter in the treatment of plural infection showed no significant differences in any impairment in clinical outcome except insertion discomfort between small- and large-diameter drains (29). Clinically, the location of the chest tube is more relevant than the tube size, and inappropriate positioning of the chest tube can cause treatment failure. The appropriate removal time of the chest tube depends on two factors: radiological confirmation of successful pleural drainage and objective evidence of infection resolution. However, the presence of loculations frequently makes the effusion difficult to discharge from pleural cavity with chest tube drainage. In the situation, intrapleural fibrinolysis, VATS, or open surgery is needed.

\section{Fibrinolysis}

Intrapleural fibrinolytic therapy was first reported in the late 1940s. Tillett and Sherry (30) used a partially purified streptococcal concentrate containing streptokinase and streptococcal deoxyribonuclease (DNase) intrapleurally in patients with fibrinopurulent pleura and empyema. To date, 11 randomized controlled trials have been performed since 2000, including both adults and children (Table 4). Of these trials, the largest are Multicenter Intrapleural Sepsis Trials 1 and 2 (MIST-1 and MIST-2) (31,41). MIST-1 showed that streptokinase at 250,000 IU twice daily for 3 days increased the amount of pleural fluid drainage, however, which was not associated with reduced mortality, lower surgical referral, or duration of hospital stay (41). MIST-2 was a randomized double-blinded, placebo-controlled trial for adult patients with pleural infection (34). This study showed that combined intrapleural tissue plasminogen activator (tPA)/DNase resulted in a significant reduction of pleural effusion in radiograph, a lower frequency of surgery, and decreased duration of hospital stay compared with placebo. 
Table 4 Randomized controlled trials of fibrinolytic treatment reported since 2000

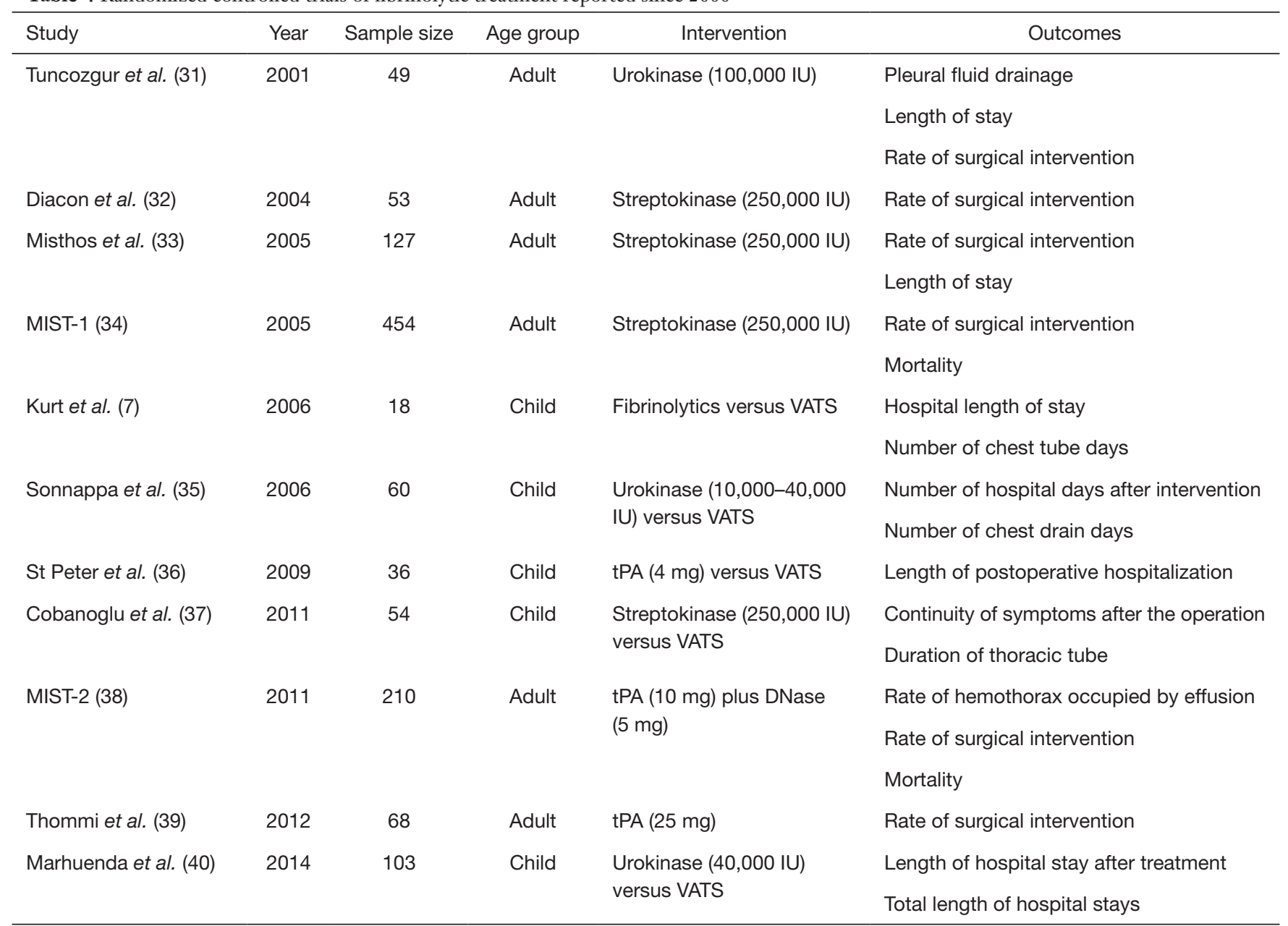

VATS, video-assisted thoracic surgery; tPA, tissue plasminogen activator; Dnase, deoxyribonuclease. MIST, Multicenter Intrapleural Sepsis Trial.

\section{Streptokinase}

The most commonly used fibrinolytic in the clinical setting is streptokinase, and several prospective studies have proven the efficacy of this agent for thoracic empyema (Table 4) $(32,38)$. A total of 250,000 IU of streptokinase was administered into the pleural space for 3 to 7 days. However, the optimal dosage and required number of daily washings of streptokinase are still controversial. Furthermore, according to the negative results of MIST-1, streptokinase is giving way to other fibrinolytics such as urokinase, tPA, and DNase.

\section{Urokinase}

Urokinase is a thrombolytic agent derived from human neonatal kidney cells. Some case reports have shown that urokinase therapy improves pleural fluid drainage and reduces the need for further surgical intervention $(33,42)$.
In addition to these retrospective studies, some randomized clinical trials have shown that urokinase therapy increases pleural fluid drainage and reduces the referral rate for surgery $(43,44)$. Tuncozgur et al. (45) also showed that intrapleural instillation of urokinase (100,000 IU/day) provided a better outcome and reduced the need for decortication (Table 4). These randomized trials have increased the level of clinical evidence.

\section{Ozone}

The benefits of ozone therapy have been studied for more than a century. Ozone has been demonstrated to be a forceful and reliable antimicrobial agent against bacteria, fungi, and viruses (31). Ozone induces the destruction of cytoplasmic membranes of bacteria and fungi by acting on glycoproteins, glycolipids, and other amino acids as 
well as by inhibiting key enzymes in the cells. Through these actions, microbial cell death occurs (31). Ozone can also be widely spread into the abscess cavity, resulting in abscess wall dehydration and expand the distribution of drug solutions (31). A retrospective study showed that combined treatment with ozone and urokinase is useful in the management of empyema and can safely reduce the rate of surgical referrals and the duration of hospital stay (46). The authors injected $50,000 \mathrm{U}$ of urokinase diluted in $20 \mathrm{~mL}$ of normal saline into the pleural cavity through a pigtail catheter. In addition to urokinase, 10 to $20 \mathrm{~mL}$ of an oxygen-ozone gas mixture (ozone concentration of $25 \mathrm{mcg} / \mathrm{mL}$ ) was administered through the catheter per day (46). A randomized prospective study is needed to assess the role of ozone in the treatment of this entity.

\section{DNase}

DNase synergizes with tPA or streptokinase in vitro and in animal models of empyema (47). MIST-2 (34) (Table 4) demonstrated that the combination of intrapleural tPA (10 mg twice a day for 3 days) and DNase (5 mg twice a day for 3 days) resulted in statistically significant clinical improvement in pleural fluid drainage and a reduction in the length of hospital stay compared with the other three treatments (tPA, DNase, and placebo). Furthermore, a $75 \%$ reduction of surgical referral at 3 months was achieved in the tPA-DNase group compared with the placebo group (34). Six serious adverse events occurred in the study: two cases of intrapleural hemorrhage (both in the tPA-DNase group), one case of hemoptysis (in the placebo group), two episodes of gastrointestinal bleeding (both in the DNase group), and one case of clinical deterioration (in the placebo group). The frequency of adverse events did not significantly differ among the groups (34). Thommi et al. (48) also showed the efficacy and safety of tPA for thoracic empyema in their doubleblind randomized crossover trial.

\section{VATS}

VATS can be performed in patients whose chest tube drainage has failed or when the lung does not re-expand well after medical management. One retrospective study showed fewer complication and higher success with early treatment by VATS when compared with delayed surgery (39). In other studies, VATS debridement resulted in shorter hospital stays and superior empyema improvement rates when compared with chest tube drainage $(49,50)$. Current guidelines advocate the use of surgery when an advanced fibrinopurulent phase is suspected by the presence of extensive pleural thickening that requires decortication (20). The need for surgery is usually assessed 5 to 7 days after initial treatment for empyema $(51,52)$. Currently, VATS is considered as the primary treatment option for stage II empyema. However, the guidelines are based on low-quality evidence, and there are no reliable data to identify which patients are likely to benefit from surgical treatment or determine the optimal time point for referral to a surgeon. The recently proposed RAPID score enables clinicians to prognosticate at the time of presentation (53). VATS or open intervention remains the standard option for treating complicated pleural effusion or empyema. The American Association for Thoracic Surgery consensus guidelines for the management of empyema recently classified VATS as a class IIa recommendation (24). According to this recommendation, VATS is considered to be the primary treatment in stage II (fibrinopurulent phase) patients (level of evidence B), and intrapleural fibrinolytics should not be used primarily for both complicated pleural effusion and early empyema (level of evidence B) (24). The European Association of Cardiothoracic Surgery expert consensus statement for surgical management of pleural empyema demonstrated benefits of VATS decortication for stage II and III empyema, which are tolerable conditions for treatment with an operative procedure (54). A recent systematic review and meta-analysis compared VATS and chest drainage with fibrinolysis in the management of pediatric empyema (55). The authors evaluated previous randomized trials $(7,35-37,40)$ and found that VATS and chest drainage with fibrinolysis for empyema in children have a similar incidence of perioperative complications and that VATS tends to reduce the need for re-intervention and is associated with a shorter postoperative hospital stay (55).

\section{Open surgery}

\section{Decortication}

For several decades, open decortication remained the only surgical treatment for complicated empyema (56). Open decortication has been adapted to remove fibrous tissue and peel from the parietal and visceral pleura in order to improve lung expansion, resulting in a greater lung vital capacity and improvement in symptoms. A recent analysis demonstrated equivalent effectiveness of VATS decortication in the management of advanced stage II or III empyema (57). However, the study showed no superior results with VATS versus open surgery decortication in 
the treatment of thoracic empyema. Therefore, VATS and open thoracotomy decortication can be recommended in the surgical management of thoracic empyema. However, in advanced empyema patients, VATS can be easily leaded to the conversion to an open surgery. According to these research findings, open decortication is saved for unresolved empyema.

\section{Open window thoracotomy (fenestration)}

Dr. Leo Eloesser, the surgeon who developed the surgical procedure associated with his name, reported in 1935 its use as an alternative to existing treatment for acute tuberculous empyema that were associated with high mortality (58). In his original report of the operation (Eloesser's method), he constructed the window with a flap so that it functioned as a one-way valve, carrying out the fluid from pleural cavity while preventing air from entering the pleural cavity and causing lung collapse. This procedure requires partial resection of two to three ribs and creation of a U-shaped soft tissue flap that is folded into the chest cavity. Thourani et al. (59) subsequently proposed the modified Eloesser flap, which uses an inverted U-shaped muscle flap. Open window thoracotomy still remains a life-saving treatment option for patients with pleural cavity infection, especially in patients with bronchopleural fistulas (BPFs). This method requires resection of two to three ribs and careful separation of the chest wall muscles, which results in a segmental defect of the chest wall and a poor cosmetic appearance. Novel prosthetic devices for open thoracotomy, which require only a $3 \mathrm{~cm}$ resection in one rib, have been shown to be effective for resolving chronic empyema $(60,61)$. These prostheses are self-retained silicone tubes, which drain out into a small plastic bag. Another novel device, the vacuum-assisted closure device (negative-pressure wound therapy), might help the management of patients with empyema by hastening recovery $(62,63)$. However, the previous American Association for Thoracic Surgery expert consensus guidelines warned that the vacuumassisted closure method should be used with caution in the presence of a BPF or visceral pleural fistula (24). This open window thoracotomy technique has a specific advantage in the successful closure of BPF $(64,65)$. In patients with a BPF, bronchial occlusion is necessary and an Endobronchial Watanabe Spigot (Novatech, Grasse, France) is sometimes used to decrease air leakage and thus avoid fenestration (66).

\section{Management of residual thoracic space}

Three approaches are used for treatment of the residual thoracic space. The first is a permanent open thoracotomy window. Second, the space can be closed and filled with antibiotic solution (Clagett procedure) (67) after achieving good control of the infection. The third approach requires plombage (pneumolysis) of the thoracic cavity with a pedicle muscle or omental flap with or without a partial thoracoplasty. The choice of biomaterials varies and depends on the surgeon's preference, location of the residual thoracic space, and previous damage of muscles by prior surgery. The latissimus dorsi muscle, anterior serratus muscle, major pectoral muscle, greater omentum, or a combination of these organs are frequently used and can achieve successful results (68). Thoracomyoplasty is being increasingly used as a definitive approach to manage complicated empyema, especially in patients with a BPF (69-71).

\section{Recent topics and forward agenda}

Currently, the most reliable infection biomarkers are $\mathrm{C}$-reactive protein and procalcitonin. In addition to these, soluble triggering receptor expressed on myeloid cells (STREM-1) is a promising biomarker in diagnosing pleural infection and deciding whether to use chest tube drainage $(72,73)$. A large prospective study is urgently needed to evaluate this biomarker in the near future.

The development of fibrinolytic agents is remarkable in the field of fibrinolytic therapy. In the coagulation cascade, a crucial factor of this reaction is the resolve of plasminogen into plasmin by tPA, which competes with inhibitory substances such as plasminogen activator inhibitor (PAI)-1 and -2 (74). The PAI-1 concentration is elevated within locules and is therefore likely to contribute to the formation of pleural septations (75). These facts have encouraged to target this specific pathway. PAI1-targeting monoclonal antibodies can be used as adjunctive therapy (76). Lansley et al. (77) theorized that the injection of tPA itself induces pleural fluid production. Their experiment on mice revealed that monocyte chemotactic protein-1 (MCP-1) involved in tPA-induced pleural effusion formation. They also found that MCP1 antagonists could inhibit large effusion formation with intrapleural fibrinolysis (77). No prospective studies have yet been performed to evaluate fibrinolytic agents (Table 4), although some prospective studies comparing various fibrinolytics or surgical intervention versus fibrinolytics are ongoing (Table 5). These studies will contribute to the establishment of future guidelines. 
Table 5 Ongoing prospective randomized controlled trials

\begin{tabular}{|c|c|c|c|c|c|c|c|c|c|}
\hline $\begin{array}{l}\text { ClinicalTrials. } \\
\text { gov Identifier }\end{array}$ & Phase & $\begin{array}{l}\text { Sample } \\
\text { size }\end{array}$ & $\begin{array}{l}\text { Age } \\
\text { group }\end{array}$ & Status & Intervention & Primary outcome & Country & $\begin{array}{l}\text { Study start } \\
\text { date }\end{array}$ & $\begin{array}{c}\text { Study } \\
\text { completion } \\
\text { date }\end{array}$ \\
\hline NCT02014077 & NA & 100 & Adult & Recruiting & $\begin{array}{c}\text { VATS versus } \\
\text { thoracotomy } \\
\text { tube }\end{array}$ & $\begin{array}{l}\text { Duration of } \\
\text { hospital stay }\end{array}$ & $\begin{array}{l}\text { South } \\
\text { Africa }\end{array}$ & $\begin{array}{c}\text { January 1, } \\
2014\end{array}$ & $\begin{array}{l}\text { March 31, } \\
2020\end{array}$ \\
\hline NCT03716375 & NA & 80 & Child & $\begin{array}{l}\text { Not yet } \\
\text { recruiting }\end{array}$ & Urokinase & $\begin{array}{c}\text { Length of } \\
\text { hospital stay }\end{array}$ & China & $\begin{array}{c}\text { November } 1, \\
2018\end{array}$ & $\begin{array}{c}\text { April 30, } \\
2020\end{array}$ \\
\hline NCT03859206 & NA & 60 & Adult & $\begin{array}{l}\text { Not yet } \\
\text { recruiting }\end{array}$ & $\begin{array}{l}\text { Medical } \\
\text { thoracoscopy } \\
\text { versus tube } \\
\text { thoracostomy }\end{array}$ & $\begin{array}{c}\text { Medical } \\
\text { cure without } \\
\text { secondary } \\
\text { intervention }\end{array}$ & Egypt & $\begin{array}{c}\text { March 1, } \\
2019\end{array}$ & May 1, 2021 \\
\hline NCT03584113 & NA & 70 & Adult & $\begin{array}{l}\text { Not yet } \\
\text { recruiting }\end{array}$ & $\begin{array}{l}\text { tPA versus } \\
\text { VATS }\end{array}$ & $\begin{array}{l}\text { Rate of re- } \\
\text { intervention }\end{array}$ & Canada & $\begin{array}{c}\text { November } \\
1,2019\end{array}$ & $\begin{array}{c}\text { July } 31 \text {, } \\
2021\end{array}$ \\
\hline NCT04095676 & NA & 184 & Adult & $\begin{array}{l}\text { Not yet } \\
\text { recruiting }\end{array}$ & $\begin{array}{c}\text { DNase versus } \\
\text { VATS }\end{array}$ & $\begin{array}{c}\text { Hospitalization } \\
\text { time }\end{array}$ & Denmark & $\begin{array}{c}\text { March 1, } \\
2020\end{array}$ & $\begin{array}{c}\text { September } \\
1,2023\end{array}$ \\
\hline NCT03583931 & NA & 36 & Adult & $\begin{array}{l}\text { Enrolling by } \\
\text { invitation }\end{array}$ & $\begin{array}{c}\text { tPA and DNase } \\
\text { versus VATS }\end{array}$ & $\begin{array}{l}\text { Hospital length } \\
\text { of stay }\end{array}$ & $\begin{array}{l}\text { United } \\
\text { States }\end{array}$ & $\begin{array}{c}\text { July } 26 \text {, } \\
2018\end{array}$ & $\begin{array}{c}\text { April 30, } \\
2024\end{array}$ \\
\hline
\end{tabular}

NA, not applicable; tPA, tissue plasminogen activator; Dnase, deoxyribonuclease; VATS, video-assisted thoracic surgery; IPFT, intrapleural fibrolytic therapy.

\section{Conclusions}

The pathophysiology of thoracic empyema varies, and affected patients' general conditions are poor. Therefore, physicians must evaluate the patients' conditions and choose the treatment strategy early in the clinical course. Thoracic empyema is undoubtedly a complex issue of which some aspects have been clarified; however, many aspects are still under discussion, such as the methods of removing loculated effusions (various fibrinolytics versus VATS), the drainage techniques (open surgery versus VATS), the best timing of these treatments, and so on. For these reasons, thoracic empyema has thus not been treated on the basis of evidence from prospective studies as on the empirical basis. Multicenter controlled clinical trials are needed to resolve these problems, and widely accepted guidelines for the treatment of empyema must be established.

\section{Acknowledgments}

The authors thank Angela Morben, DVM, ELS, from Edanz Group (www.edanzediting.com/ac), for editing a draft of this manuscript.

Funding: None.

\section{Footnote}

Provenance and Peer Review: This article was commissioned by the Guest Editor (Satoshi Shiono) for the series "Empyema" published in Current Challenges in Thoracic Surgery. The article has undergone external peer review.

Conflicts of Interest: Both authors have completed the ICMJE uniform disclosure form (available at https://ccts. amegroups.com/article/view/10.21037/ccts.2020.02.09/ 
coif). The series "Empyema" was commissioned by the editorial office without any funding or sponsorship. The authors have no other conflicts of interest to declare.

Ethical Statement: The authors are accountable for all aspects of the work in ensuring that questions related to the accuracy or integrity of any part of the work are appropriately investing and resolved.

Open Access Statement: This is an Open Access article distributed in accordance with the Creative Commons Attribution-NonCommercial-NoDerivs 4.0 International License (CC BY-NC-ND 4.0), which permits the noncommercial replication and distribution of the article with the strict proviso that no changes or edits are made and the original work is properly cited (including links to both the formal publication through the relevant DOI and the license). See: https://creativecommons.org/licenses/by-nc-nd/4.0/.

\section{References}

1. Christopoulou-Aletra H, Papavramidou N. "Empyemas" of the thoracic cavity in the Hippocratic Corpus. Ann Thorac Surg 2008;85:1132-4.

2. Chen W, Lin Y, Liang S, et al. Hospital-acquired thoracic empyema in adults: a 5-year study. South Med J 2009;102:909-14.

3. Liang SJ, Chen W, Lin Y, et al. Community-acquired thoracic empyema in young adults. South Med J 2007;100:1075-80.

4. Ferguson AD, Prescott RJ, Selkon JB, et al. The clinical course and management of thoracic empyema. QJM 1996;89:285-9.

5. Tassi GF, Marchetti GP. Pleural disease: historic perspective. In: Light RW, Gary Lee YC. editors. Textbook of Pleural Diseases. 2nd edition. London: Hodder Arnold, 2008;1-9.

6. Coote N, Kay E, Coote N. Surgical versus non-surgical management of pleural empyema. Cochrane Database Syst Rev 2005;(4):CD001956.

7. Kurt BA, Winterhalter KM, Connors RH, et al. Therapy of parapneumonic effusions in children: video-assisted thoracoscopic surgery versus conventional thoracotomy drainage. Pediatrics 2006;118:e547-53.

8. Yao CT, Wu JM, Liu CC, et al. Treatment of complicated parapneumonic pleural effusions with intrapleural streptokinase in children. Chest 2004;125:566-71.

9. Cochran JB, Tecklenburg FW, Turner RB. Intrapleural instillation of fibrinolytic agents for treatment of pleural empyema. Pediatr Crit Care Med 2003;4:39-43.

10. Ulku R, Onat S, Kiliç N. Intrapleural fibrinolytic treatment of multiloculated pediatric empyemas. Minerva Pediatr 2004;56:419-23.

11. Farjah F, Symons RG, Krishnadasan B, et al. Management of pleural space infections: a population-based analysis. J Thorac Cardiovasc Surg 2007;133:346-51.

12. Shimizu H, Endo S, Natsugoe S, et al. Thoracic and cardiovascular surgery in Japan in 2016. Gen Thorac Cardiovasc Surg 2019;67:377-411.

13. Grijalva CG, Zhu Y, Nuorti JP, et al. Emergence of parapneumonic empyema in the USA. Thorax 2011;66:663-8.

14. Andrew NC, Parker EF, Shaw RP, et al. Management of nontuberculous empyema. A statement of the subcommittee on surgery. Am Rev Respir Dis 1962;85:935-6.

15. Wozniak CJ, Paull DE, Moezzi JE, et al. Choice of first intervention is related to outcomes in the management of empyema. Ann Thorac Surg 2009;87:1525-30.

16. Luh SP, Chou MC, Wang LS, et al. Video-assisted thoracoscopic surgery in the treatment of complicated parapneumonic effusions or empyemas: outcome of 234 patients. Chest 2005;127:1427-32.

17. Deslauriers J, Mehran R. Handbook of Perioperative Care in General Thoracic Surgery. 1st edition. Philadelphia: Mosby, 2005.

18. Light RW. A new classification of parapneumonic effusions and empyema. Chest 1995;108:299-301.

19. Colice GL, Curtis A, Deslauriers J, et al. Medical and surgical treatment of parapneumonic effusions: an evidence-based guideline. Chest 2000;118:1158-71.

20. Davies HE, Davies RJO, Davies CWH. Management of pleural infection in adults: British Thoracic Society pleural disease guideline 2010. Thorax 2010;65:ii41-53.

21. Heffner JE, Klein S, Hampson C. Diagnostic utility and clinical application of imaging for pleural space infections. Chest 2010;137:467-9.

22. Moffett BK, Panchabhai TS, Anaya E, et al. Computed tomography measurements of parapneumonic effusion indicative of thoracentesis. Eur Respir J 2011;38:1406-11.

23. Brutsche MH, Tassi GF, Gyorik S, et al. Treatment of sonographically stratified multiloculated thoracic empyema by medical thoracoscopy. Chest 2005;128:3303-9.

24. Shen KR, Bribriesco A, Crabtree T, et al. The American Association for Thoracic Surgery consensus guidelines for the management of empyema. J Thorac Cardiovasc Surg 
2017;153:e129-46.

25. Berger HA, Morganroth ML. Immediate drainage is not required for all patients with complicated parapneumonic effusions. Chest 1990;97:731-5.

26. Poe RH, Matthew GM, Istael RH, et al. Utility of pleural fluid analysis in predicting tube thoracostomy/ decortication in parapneumonic effusions. Chest 1991;100:963-7.

27. Smith JA, Mullerworth MH, Westlake GW, et al. Empyema thoracis: 14-year experience in a teaching center. Ann Thorac Surg 1991;51:39-42.

28. Redden MD, Chin TY, van Driel ML. Surgical versus non-surgical management for pleural empyema. Cochrane Database Syst Rev 2017;3:CD010651.

29. Rahman NM, Maskell NA, Davies CW, et al. The relationship between chest tube size and clinical outcome in pleural infection. Chest 2010;137:536-43.

30. Tillett WS, Sherry S. The effect in patients of streptococcal fibrinolysin (streptokinase) and streptococcal deoxyribonuclease on fibrinous, purulent, and sanguineous pleural exudations. J Clin Invest 1949;28:173-90.

31. Elvis AM, Ekta JS. Ozone therapy: a clinical review. J Nat Sci Biol Med 2011;2:66-70.

32. Misthos P, Sepsas E, Konstantinou M, et al. Early use of intrapleural fibrinolytics in the management of postpneumonic empyema. A prospective study. Eur J Cardiothorac Surg 2005;28:599-603.

33. Moulton JS, Moore PT, Mencini RA. Treatment of loculated pleural effusions with transcatheter intracavitary urokinase. AJR Am J Roentgenol 1989;153:941-5.

34. Rahman NM, Maskell NA, West A, et al. Intrapleural use of tissue plasminogen activator and DNase in pleural infection. N Engl J Med 2011;365:518-26.

35. Sonnappa S, Cohen G, Owens CM, et al. Comparison of urokinase and video-assisted thoracoscopic surgery for treatment of childhood empyema. Am J Respir Crit Care Med 2006;174:221-7.

36. St Peter SD, Tsao K, Spindle TL, et al. Thoracoscopic decortication vs tube thoracostomy with fibrinolysis for empyema in children: a prospective, randomized trial. J Pediatr Surg 2009;44:1865.

37. Cobanoglu U, Sayir F, Bilici S, et al. Comparison of the methods of fibrinolysis by tube thoracostomy and thoracoscopic decortication in children with stage II and III empyema: a prospective randomized study. Pediatr Rep 2011;3:e29.

38. Diacon AH, Theron J, Schuurmans MM, et al. Intrapleural streptokinase for empyema and complicated parapneumonic effusions. Am J Respir Crit Care Med 2004;170:49-53.

39. Chen LE, Langer JC, Dillon PA, et al. Management of late-stage parapneumonic empyema. J Pediatr Surg 2009;44:106-11; discussion 111.

40. Marhuenda C, Barcelo C, Fuentes I, et al. Urokinase versus VATS for treatment of empyema: a randomized multicenter clinical trial. Pediatrics 2014;134:e1301-7.

41. Maskell NA, Davies CW, Nunn AJ, et al. U.K. controlled trial of intrapleural streptokinase for pleural infection. $\mathrm{N}$ Engl J Med 2005;352:865-74.

42. Lee KS, Im JG, Kim YH, et al. Treatment of thoracic multiloculated empyemas with intracavitary urokinase: a prospective study. Radiology 1991;179:771-5.

43. Bouros D, Schiza S, Patsourakis G, et al. Intrapleural streptokinase versus urokinase in the treatment of complicated parapneumonic effusions: a prospective, double-blind study. Am J Respir Crit Care Med 1997;155:291-5.

44. Bouros D, Schiza S, Tzanakis N, et al. Intrapleural urokinase versus normal saline in the treatment of complicated parapneumonic effusions and empyema. A randomized, double-blind study. Am J Respir Crit Care Med 1999;159:37-42.

45. Tuncozgur B, Ustunsoy H, Sivrikoz MC, et al. Intrapleural urokinase in the management of parapneumonic empyema: a randomized controlled trial. Int J Clin Pract 2001;55:658-60.

46. Li B, Liu C, Li Y, et al. Computed tomographyguided catheter drainage with urokinase and ozone in management of empyema. World J Radiol 2017;9:212-6.

47. Zhu Z, Hawthorne ML, Guo Y, et al. Tissue plasminogen activator combined with human recombinant deoxyribonuclease is effective therapy for empyema in a rabbit model. Chest 2006;129:1577-83.

48. Thommi G, Shehan JC, Robinson KL, et al. A double blind randomized cross over trial comparing rate of decortication and efficacy of intrapleural instillation of alteplase vs placebo in patients with empyemas and complicated parapneumonic effusions. Respir Med 2012;106:716-23.

49. Gossot D, Stern JB, Galetta D, et al. Thoracoscopic management of postpneumonectomy empyema. Ann Thorac Surg 2004;78:273-6.

50. Cremonesini D, Thomson AH. How should we manage empyema: antibiotics alone, fibrinolytics, or primary videoassisted thoracoscopic surgery (VATS)? Semin Respir Crit Care Med 2007;28:322-32. 
51. Mavroudis C, Symmonds JB, Minagi H, et al. Improved survival in management of empyema thoracis. J Thorac Cardiovasc Surg 1981;82:49-57.

52. Pothula V, Krellenstein DJ. Early aggressive surgical management of parapneumonic empyemas. Chest 1994;105:832-6.

53. Rahman NM, Hahan BC, Miller RF, et al. A clinical score (RAPID) to identify those at risk for poor outcome at presentation in patients with pleural infection. Chest 2014;145:848-55.

54. Scarci M, Abah U, Solli P, et al. EACTS expert consensus statement for surgical management of pleural empyema. Eur J Cardiothorac Surg 2015;48:642-53.

55. Pacilli M, Nataraja RM. Management of paediatric empyema by video-assisted thoracoscopic surgery (VATS) versus chest drain with fibrinolysis: systematic review and meta-analysis. Paediatr Respir Rev 2019;30:42-8.

56. Grotenhuis BA, Janssen PJ, Eerenberg JP. The surgical treatment of stage III empyema: the effect on lung function. Minerva Chir 2008;63:23-7.

57. Sokouti M, Sadeghi R, Pashazadeh S, et al. Treating empyema thoracis using video-assisted thoracoscopic surgery and open decortication procedures: a systematic review and meta-analysis by meta-mums tool. Arch Med Sci 2019;15:912-35.

58. Eloesser L. An operation for tuberculous empyema. Surg Gynecol Obstet 1935;60:1096-7.

59. Thourani VH, Lancaster RT, Mansour KA, et al. Twentysix years of experience with the modified Eloesser flap. Ann Thorac Surg 2003;76:401-5.

60. Filomeno LT, Campos JR, Machuca TN, et al. Prosthesis for open pleurostomy (POP): management for chronic empyemas. Clinics (Sao Paulo) 2009;64:203-8.

61. de Azevedo-Pereira AE. Prosthesis for open pleurostomy versus open thoracic window. Clinics (Sao Paulo) 2009;64:598.

62. Corcoran JP, Wrightson JM, Belcher E, et al. Pleural infection: past, present, and future directions. Lancet Respir Med 2015;3:563-77.

63. Palmen M, van Breugel H, Geskes GG, et al. Open window thoracostomy treatment of empyema is accelerated by vacuum-assisted closure. Ann Thorac Surg 2009;88:1131-6

64. Shiraishi Y. Surgical treatment of chronic empyema. Gen Thorac Cardiovasc Surg 2010;58:311-6.

65. Maruyama R, Ondo K, Mikami K, et al. Clinical course and management of patients undergoing open window thoracostomy for thoracic empyema. Respiration
2001;68:606-10.

66. Sekimura A, Yoshimatsu T, Yamashita N, et al. Endobronchial Watanabe Spigot in treating pleural empyema with fistula. Kyobu Geka 2017;70:163-8.

67. Clagett OT, Geraci JE. A procedure for the management of postpneumonectomy empyema. J Thorac Cardiovasc Surg 1963;45:141-5.

68. Botianu PV, Botianu AM, Dobrica AC, et al. Intrathoracic transposition of the serrates anterior muscle flap: personal experience with 65 consecutive patients. Eur J Cardiothorac Surg 2010;38:669-73.

69. Okumura Y, Takeda S, Asada H, et al. Surgical results for chronic empyema using omental pedicled flap: long-term follow-up study. Ann Thorac Surg 2005;79:1857-61.

70. Botianu PV, Cobrica AC, Butiurca A, et al. Complex apace-filling procedures for intrathoracic infections: personal experience with 76 consecutive cases. Eur J Cardiothorac Surg 2010;37:478-81.

71. Molnar TF. Current surgical treatment of thoracic empyema in adults. Eur J Cardiothorac Surg 2007;32:422-30.

72. Dixon G, Lama-Lopez A, Bintcliffe OJ, et al. The role of serum procalcitonin in establishing the diagnosis and prognosis of pleural infection. Respir Res 2017;18:30.

73. Zou MX, Zhou RR, Wu WJ, et al. The use of pleural fluid procalcitonin and C-reactive protein in the diagnosis of parapneumonic pleural effusions: a systemic review and meta-analysis. Am J Emerg Med 2012;30:1907-14.

74. Idell S. The pathogenesis of pleural space loculation and fibrosis. Curr Opin Pulm Med 2008;14:310-5.

75. Chung CL, Chen CH, Sheu JR, et al. Proinflammatory cytokines, transforming growth factor-beta 1 , and fibrinolytic enzymes in loculated and free-flowing pleural exudates. Chest 2005;128:690-7.

76. Florova G, Azghani A, Karandashova S, et al. Targeting of plasminogen activator inhibitor 1 improves fibrinolytic therapy for tetracycline-induced pleural injury in rabbits. Am J Respir Cell Mol Biol 2015;52:429-37.

77. Lansley SM, Cheah HM, Varano Della Vergiliana JF, et al. Tissue plasminogen activator potently stimulates pleural effusion via a monocyte chemotactic protein-1-dependent mechanism. Am J Respir Cell Mol Biol 2015;53:105-12.

doi: $10.21037 /$ ccts.2020.02.09

Cite this article as: Higuchi M, Suzuki H. Current status and prospect of medical and surgical management for thoracic empyema. Curr Chall Thorac Surg 2020;2:39. 